\title{
The Link Between Indoor Air Pollution From Cooking Fuels and Anemia Status Among Non-pregnant Women of Reproductive Age in Ethiopia.
}

\section{Girum Gebremeskel Kanno}

College of Health and medical Science, school of Public health, Dilla University, Dilla Ethiopia https://orcid.org/0000-0001-6689-1983

\section{Temesgen Geremew}

Austrian Red Cross International Cooperation

\section{Tesfaye Diro}

International organization for Migration

\section{Stephen Vincent Musarapasi}

Zimbabwe Environmental Health Association

\section{Renay Van wyk}

Department of Environmental Health, Faculty of Health Science, University of Johannesburg

\section{Biniam Tariku Sabokaa}

College of Health and medical Science, school of Public health, Dilla University, Dilla Ethiopia

\section{Awash Alembo}

College of Health and medical Science, school of Public health, Dilla University, Dilla Ethiopia

\section{Robel Hussen}

College of Health and Medical Science, School of Public Health, Dilla University, Dilla, Ethiopia

\section{Negasa Eshete Soboksa}

College of Health and Medical Science, School of Public Health, Dilla University, Dilla, Ethiopia Mekonnen Birhane Aregu ( $\square$ mokebir16@gmail.com )

College of Health and Medical Science, School of Public Health, Dilla University, Dilla, Ethiopia

\section{Research Article}

Keywords: Anemia, Demographic and Health Survey, Fuel Type, non-pregnant women, Ethiopia

Posted Date: September 16th, 2021

DOI: https://doi.org/10.21203/rs.3.rs-909454/v1

License: (c) (1) This work is licensed under a Creative Commons Attribution 4.0 International License. Read Full License 


\section{Abstract}

The effect of indoor air pollution from different fuel types on the anemia status among non-pregnant women of reproductive ages is rarely studied. This study aimed to assess the link between indoor air pollution from different fuel types and anemia among non-pregnant women of reproductive ages in Ethiopia. The secondary data from the 2016 Ethiopian Demographic and Health Survey data have been employed for this study. The women of reproductive age who were not pregnant at the time of the data collection were the study population and their anemia status was the outcome variable with multiple outcomes as (moderate to severe, mild, and no anemia) and households using biomass fuel and clean fuel were selected for this study. Multinomial logistic regression was employed to estimate the association of biomass fuel use with the anemia status of women in reproductive age controlling for age, body mass index, education level, exposure to household tobacco smoke, type of residence, wealth index, and region. Adjusted Odds Ratio (AOR) was calculated at 95\% Confidence Interval. An independent sample t-test was used to assess the mean difference in blood Hemoglobin level $(\mathrm{g} / \mathrm{dl})$ between biomass and clean fuel users. For all statistical tests, a $p$-value $<0.05$ was considered significant. The proportion of anemia in women of reproductive age in Ethiopia was $41.8 \%$ and $19.4 \%$ among biomass fuel and clean fuel users respectively. The mean blood hemoglobin level was $127.17( \pm 18.063) \mathrm{g} / \mathrm{dl}$. In the multivariable multinomial logistic regression analysis, women of reproductive age who utilize biomass fuel for cooking were $33 \%$ more likely to have mild anemia than households who use cleaner fuels, whereas the association of biomass fuel use with moderate to severe anemia was insignificant. When compared with non-pregnant women who use clean energy types, women who live in households that use biomass fuel have a lower $(5.8 \mathrm{~g} / \mathrm{dl})$ blood Hemoglobin level $P<0.001$. The finding indicated that the use of biomass fuel was associated with reduced blood Hemoglobin levels and significantly associated with mild anemia levels in women of reproductive age in Ethiopia. Interventions that reduce or prevent indoor air pollution from biomass fuels must be implemented in Ethiopia.

\section{Introduction}

- Anemia is an adverse public health condition characterized by reduced oxygen-carrying capacity by the red blood cells or low blood hemoglobin concentration ( $120 \mathrm{~g} / \mathrm{L}$ for non-pregnant women) which is inadequate to meet the physiologic needs of the body [1-3]. It is one of the most important public health challenges to women, where it affects more than 500 million women in the reproductive age group and more than 32 million pregnant women globally [1, 4-5]. Preschool-aged children (47.4\%), are the most affected segment of the population by anemia followed by pregnant women (41.8\%) and women of reproductive age (30.2\%) globally [6].

- As the World Health Organization, (WHO) estimate indicated, women from developing countries are almost three times (50\%) more anemic than women from developed nations (18\%), where Africa and Asia being the worst affected continents with 60 and $52 \%$ of their women are estimated to be anemic respectively [7]. 
The problem in Ethiopia is more severe when compared to other developing countries where more than $62.7 \%$ of pregnant and $52.3 \%$ non-pregnant women are affected by anemia [8]. Anemia during the reproductive years specifically among non-pregnant women is highly important because of its impact on the woman's nutritional status during early pregnancy, and a significant proportion of women enter pregnancy with anemia in many developing countries [13].

Even if, the majority (75\%) of anemia occurrences are attributed to iron deficiency [9], nutritional deficiencies (including folate, vitamin B12, and vitamin A), parasitic infections, infectious diseases like TB, HIV, and maternal blood loss through menstruation are common causes of anemia in developing countries $[1,10-12]$. One of the least studied causes of anemia in non-pregnant women is an inflammation that resulted from exposure to indoor air pollution from either tobacco smoking or the use of biomass fuels. Findings from developing countries using national data indicated that exposure to biomass fuel smoke was linked with anemia in children and pregnant women [14-16]. But little is known about the effect of these biomass fuels or tobacco smoking on the anemia status of non-pregnant women of reproductive age in Ethiopia.

So many noxious gases such as $\mathrm{CO}, \mathrm{SO}_{2}$ and, $\mathrm{NO}_{2}$ are emitted when biomass fuels are utilized for cooking, heating, and lighting in the indoor environment in most developing countries, where most of the population is dependent on biomass fuels for cooking and the most vulnerable groups for the pollution are mainly women[15,17-18]. Therefore, this research aimed to assess the link between exposure to indoor air pollution from different fuel types and the anemia status among non-pregnant women of reproductive age in Ethiopia.

\section{Methods}

\section{Study Area and period}

The 2016 Ethiopian Demographic and Health Survey data was employed for this study. It was a nationwide survey intended to provide up-to-date estimates of key demographic and health indicators. Ethiopia, with a projected total population of $118,218,249$ by 2021 according to World population review [19], is the most populous country in East Africa, and the second-most populous country in Africa where the majority (93\%) Ninety-three percent of households use some type of solid fuel for cooking mainly would for domestic energy needs [20]. The country is divided into 9 regions (Oromiya, Amhara, SNNPR, Benishangul-Gumuz, Tigray, Afar, Somali, Gambela, and Harari) with two city administrations (Addis Ababa and Dire Dawa) which is further sub-divided into zonal administration then into Woreda for administrative purpose. The Woreda is also divided into kebele which is the smallest administrative unit.

\section{Study design, sampling technique, and data collection}

We have conducted a cross-sectional study using the survey of the 2016 Ethiopian demographic and health survey (DHS) data. This survey was carried out by the Ethiopian central statistics agency (CSA) with the Ministry of Health $(\mathrm{MoH})$ under the ICF technical assistance using a census frame of a complete 
list of 84,915 enumeration areas (EAs) created for 2007. the survey employed a two-stage stratified sampling to select eligible residential households across 645 enumeration areas (EAs). Each region was stratified into urban and rural areas, giving 21 sampling strata. Samples of EAs were selected independently in each stratum in two stages.

\section{Dependent variable}

The data collected regarding blood hemoglobin level was used as a base for categorizing the anemia status of non-pregnant women of reproductive age. The blood samples for anemia testing were taken from voluntarily consented non-pregnant by capturing a drop of blood from their finger prick and collected in a microcuvette. The analysis to determine the blood Hemoglobin level was conducted on-site using a battery-operated portable HemoCue analyzer. After the onsite analysis, the concentration of blood hemoglobin from each sample was measured in $\mathrm{g} / \mathrm{dl}$. The World Health organizations (WHO) criteria were used to categorize the non-pregnant women's anemia status using their hemoglobin $(\mathrm{Hb})$ level. Hence, the non-pregnant women were categorized as not anemic $(\mathrm{Hb} \geq 12.0 \mathrm{~g} / \mathrm{dl})$, mildly anemic $(10.0-11.9 \mathrm{~g} / \mathrm{dl})$, moderately anemic $(7.0-9.9 \mathrm{~g} / \mathrm{dl})$, or severely anemic $(\mathrm{Hb}<7.0 / \mathrm{dl})$ [21]. Afterward, the non-pregnant women were further categorized as not anemic and anemic.

\section{Exposure variable}

The fuel type for household energy demand was the main exposure variable. The non-pregnant women were asked during the survey "What type of fuel does your household mainly use for cooking?" to assess the main fuel types used in the household and there were eleven fuel types namely, (electricity, liquefied petroleum gas (LPG), natural gas, biogas, kerosene, coal/lignite, charcoal, wood, straw/shrubs/grass, agricultural crop, animal dung) as a response. Therefore, these were further re-categorized into biomass fuels (wood, straw, animal dung, and crop residues) and clean fuels (electricity, liquid petroleum gas, and natural gas) [22]. For this analysis medium polluting fuels were removed from the analysis, and only biomass fuel users and clean fuel users were assessed for anemia status and other predictor variables. Because of the small number, moderate and severe anemia are categorized into one variable, as 'moderate to severe anemia'.

\section{Other predictor variables}

The predictor variables included in this study were, women-related factors (the age of the women, BMI, education level, chat chewing, and parity) and socio-demographic factors (sex of head of the household, residency, and wealth index). Maternal age and BMI of the non-pregnant women in reproductive age were used as a continuous variable for the analysis and the highest education level achieved by the nonpregnant women in reproductive age was categorized as no formal schooling, primary school, secondary, and higher (university/college and above). The tobacco smoking status was labeled as 'yes' or 'No'. The residency was grouped into urban and rural while the wealth index was a five-category variable as poorest, poorer, medium, richer, and the richest. 


\section{Inclusion and exclusion criteria}

Of the total of 15683 women, 4722 of them were excluded because they didn't fulfill the inclusion criteria for this study as shown in (Figure 1) and a total of 10,961 women were enrolled for the final analysis in this study.

\section{Data analysis and sample characteristics}

We have used SPSS analysis software version 25 for the analysis. Multinomial logistic regression was employed to determine whether there was an association between the use of different fuel types and the anemia status of the non-pregnant women in reproductive age in Ethiopia. Adjusted Odds Ratio was used to measure the association and their $95 \%$ Confidence Interval was calculated. A p-value of less than 0.05 was considered for statistical significance. An independent sample t-test was used to assess the mean difference in blood Hemoglobin level $(\mathrm{g} / \mathrm{dl})$ between biomass and clean fuel users.

\section{Results}

\section{Characteristics of the study participants}

From the total of 15683 women, 10,961 non-pregnant women of reproductive age has fulfilled the inclusion criteria. The blood level ranges between (34-194) $\mathrm{g} / \mathrm{dl}$ with a mean blood hemoglobin level of $127.17( \pm 18.063) \mathrm{g} / \mathrm{dl}$. As indicated in (Table 1), the majority of $9505(86.7 \%)$ of the women live in households that use biomass fuels such as wood, belong to the poorest $3177(29 \%)$ or poorer category 1703 (15.3\%) and have no education 5473 (50\%). Rural residence 8425 (76.8\%) and male-headed households 7904 (72.1\%) were dominant among the study participants.

Table 1. Characteristics of the study participants in Ethiopia 


\begin{tabular}{|c|c|c|c|c|c|}
\hline \multirow[t]{2}{*}{ Variables } & \multirow[t]{2}{*}{ Category } & \multicolumn{3}{|c|}{ Anemia status } & \multirow[t]{2}{*}{ Total } \\
\hline & & $\begin{array}{l}\text { No anemia } \\
(\mathrm{n}=7924)\end{array}$ & $\begin{array}{l}\text { Mild } \\
(n=2236)\end{array}$ & $\begin{array}{l}\text { Moderate to severe } \\
\text { anemia }(n=801)\end{array}$ & \\
\hline \multirow[t]{2}{*}{ Fuel type } & Biomass fuel & 6704 & 2049 & 752 & $\begin{array}{l}9505 \\
(86.7 \%)\end{array}$ \\
\hline & Clean & 1220 & 187 & 49 & $\begin{array}{l}1456 \\
(13.3 \%)\end{array}$ \\
\hline \multirow[t]{2}{*}{ Residence } & Urban & 2048 & 385 & 103 & $\begin{array}{l}2536 \\
(23.2 \%)\end{array}$ \\
\hline & Rural & 5876 & 1851 & 698 & $\begin{array}{l}8425 \\
(76.8 \%)\end{array}$ \\
\hline \multirow[t]{2}{*}{$\begin{array}{l}\text { Sex of head } \\
\text { of the HH }\end{array}$} & Male & 5737 & 1590 & 577 & $\begin{array}{l}7904 \\
(72.1 \%)\end{array}$ \\
\hline & Female & 2187 & 646 & 224 & $\begin{array}{l}3057 \\
(27.9 \%)\end{array}$ \\
\hline \multirow[t]{5}{*}{ Wealth index } & Poorest & 1889 & 861 & 427 & $\begin{array}{l}3177 \\
(29 \%)\end{array}$ \\
\hline & Poorer & 1235 & 360 & 108 & $\begin{array}{l}1703 \\
(15.5 \%)\end{array}$ \\
\hline & Middle & 1254 & 331 & 92 & $\begin{array}{l}1677 \\
(15.3 \%)\end{array}$ \\
\hline & Richer & 1301 & 274 & 76 & $\begin{array}{l}1651 \\
(15.1 \%)\end{array}$ \\
\hline & Richest & 2245 & 410 & 98 & $\begin{array}{l}2753 \\
(25.1 \%)\end{array}$ \\
\hline \multirow[t]{4}{*}{ Education } & No education & 3625 & 1294 & 554 & $\begin{array}{l}5473 \\
(50 \%)\end{array}$ \\
\hline & Primary & 2793 & 663 & 174 & $\begin{array}{l}3630 \\
(33.1 \%)\end{array}$ \\
\hline & Secondary & 1006 & 205 & 50 & $\begin{array}{l}1261 \\
(11.5 \%)\end{array}$ \\
\hline & Higher & 500 & 74 & 23 & $\begin{array}{l}597 \\
(5.4 \%)\end{array}$ \\
\hline \multirow[t]{2}{*}{ Water source } & Improved & 5493 & 1397 & 425 & $\begin{array}{l}7315 \\
(66.8 \% \mathrm{C}\end{array}$ \\
\hline & Unimproved & 2431 & 839 & 376 & $\begin{array}{l}3646 \\
(33.2 \%)\end{array}$ \\
\hline Toilet facility & Improved & 1707 & 381 & 128 & $\begin{array}{l}2216 \\
(20.2 \%)\end{array}$ \\
\hline
\end{tabular}




\begin{tabular}{lcccl} 
Unimproved & 3611 & 815 & 228 & $\begin{array}{l}4654 \\
(42.5 \%)\end{array}$ \\
$\begin{array}{l}\text { No } \\
\text { facility/field/bush }\end{array}$ & 2606 & 1040 & 445 & $\begin{array}{l}4091 \\
(37.3 \%)\end{array}$ \\
\hline
\end{tabular}

\section{Types of cooking fuel types}

Wood was the major $8887(80.7 \%)$ type of fuel used in households where the women of reproductive age reside followed by electricity 1351 (10.3\%) and animal dung 497 (4.5\%). Based on the level of their pollution emitting capacity the fuel types were further categorized and the result indicated that high polluting fuel types (Biomass fuels) account for more than two-thirds of fuel types with 9505 (86.7\%) (figure 2).

\section{Anemia status among reproductive-age women in Ethiopia}

According to our finding, the proportion of anemia in non-pregnant women of reproductive age in Ethiopia was $29.4 \%$ and $16.2 \%$ among biomass fuel and clean fuel users respectively. Among the participants selected for this study, moderate to severe, and mild anemia accounts for $7.3 \%$ and $20.4 \%$ respectively (Table 2). The overall prevalence of anemia among the study participants was $27.7 \%$.

Table 2. The proportion of anemia levels among different fuel type users among non-pregnant women of reproductive age in Ethiopia

\begin{tabular}{llll} 
Anemia status & Fuel types & & \\
\cline { 2 - 4 } & Biomass fuels & Clean fuels & Total \\
\hline Moderate-Severe & 752 & 49 & $801(7.3 \%)$ \\
\hline Mild & 2049 & 187 & $2236(20.4 \%)$ \\
\hline Not anemic & 6704 & 1220 & $7924(72.3 \%)$ \\
\hline Total & $9505(86.7 \%)$ & $1456(13.3 \%)$ & $10961(100 \%)$
\end{tabular}

\section{Bivariate analysis}

As indicated in (table 3), non-pregnant women with biomass fuel use were 2.8 (95\% $\mathrm{Cl}$ 2.1-3.8) times more likely to be moderate to severe anemic and [AOR; $2.0,95 \% \mathrm{Cl} ; 1.7-2.3]$ more mildly anemic than those women who uses clean fuel types. Women who were having no education were three times more anemic than women with higher education where as, when compared with higher educated women having no education, primary, and secondary education were found to have more chance of being mildly anemic in decreasing order. All the participants in different wealth index categories were found to be 
moderate to severely and mildly anemic when compared with the richest. But the strength of the association has seen decrement from the poorest to the richer.

Table 3. Bivariate analysis of factors associated with the anemia status among women of reproductive age in Ethiopia. 
Risk factors

Fuel type

Biomass fuel

Low polluting

fuels
Mild Anemia

$\begin{array}{ll}\text { AOR } & 95 \% \\ & \mathrm{Cl}\end{array}$

2
P-

value

$\begin{array}{lll}1.7- & <0.001 & 2.8 \\ 2.3 & \end{array}$

2.3
Moderate to severe Anemia

P-

AOR $\quad 95 \% \mathrm{Cl}$

$2.1-3.8<0.001$

\begin{tabular}{|c|c|c|c|c|c|c|}
\hline & 0.99 & $\begin{array}{l}0.99- \\
0.999\end{array}$ & 0.009 & 0.986 & $\begin{array}{l}0.98- \\
0.99\end{array}$ & 0.000 \\
\hline - & 1.01 & $\begin{array}{l}1.001- \\
1.01\end{array}$ & 0.021 & 1.0 & $\begin{array}{l}0.99- \\
1.01\end{array}$ & 0.952 \\
\hline - & 1.0 & $\begin{array}{l}0.999- \\
1.0\end{array}$ & $<0.001$ & 0.999 & $\begin{array}{l}0.999- \\
0.999\end{array}$ & $<0.001$ \\
\hline Male & 0.244 & $\begin{array}{l}0.8^{-} \\
1.04\end{array}$ & 0.94 & 0.99 & $0.8-1.2$ & 0.926 \\
\hline
\end{tabular}

Age of household

head

Age of the women in

years

BMI in $\mathrm{kg} / \mathrm{m}^{2}$

Sex of head of the household

Education

Male

Female

No education

Primary

Secondary

Higher

Type of place of residence

Wealth index

$$
\text { Poorest }
$$

0.6

2.4

$1.9-<0.001$

3.1

$0.8-$
1.04

.

1.6

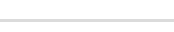

$1.4 \quad 1.0-$

1.8
$0.8-1.2 \quad 0.926$

\begin{tabular}{llllll}
0.99 & $\begin{array}{l}0.99- \\
0.999\end{array}$ & 0.009 & 0.986 & $\begin{array}{l}0.98- \\
0.99\end{array}$ & 0.000 \\
\hline 1.01 & $\begin{array}{l}1.001- \\
1.01\end{array}$ & 0.021 & 1.0 & $\begin{array}{l}0.99- \\
1.01\end{array}$ & 0.952 \\
& & & \\
1.0 & $\begin{array}{l}0.999- \\
1.0\end{array}$ & $<0.001$ & 0.999 & $\begin{array}{l}0.999- \\
0.999\end{array}$ & $<0.001$ \\
& & & $0.8-1.2$ & 0.926 \\
\hline 0.244 & $\begin{array}{l}0.8- \\
1.04\end{array}$ & 0.94 & 0.99 & 0.96 & \\
\hline
\end{tabular}

$\begin{array}{lll}1.2- & <0.001 \quad 1.3 \\ 2.1 & \end{array}$

3.2

$2.1-4.9<0.001$

$0.027 \quad 1.03$

0.6-1.7

0.909

$\begin{array}{lll}1.3 & 0.8-2.0 \quad 0.237\end{array}$ 
Yes

\begin{tabular}{|c|c|c|c|c|c|c|c|}
\hline Chewing Khat & No & 1.1 & $\begin{array}{l}0.9- \\
1.2\end{array}$ & 0.528 & 0.9 & $0.7-1.1$ & 0.203 \\
\hline & Yes & & & & & & \\
\hline $\begin{array}{l}\text { Total number of } \\
\text { household members }\end{array}$ & & 0.7 & $\begin{array}{l}0.6- \\
0.8\end{array}$ & 0.000 & 0.7 & $0.6-0.8$ & 0.000 \\
\hline \multirow[t]{2}{*}{$\begin{array}{l}\text { Number of under five } \\
\text { children }\end{array}$} & $\leq 5$ & 0.7 & $\begin{array}{l}0.6- \\
0.8\end{array}$ & 0.000 & 0.7 & $0.6-0.8$ & 0.000 \\
\hline & $>5$ & & & & & & \\
\hline \multirow[t]{3}{*}{ Toilet type } & Improved & 0.56 & $\begin{array}{l}0.5- \\
0.6\end{array}$ & 0.000 & 0.4 & $\begin{array}{l}0.35- \\
0.5\end{array}$ & 0.000 \\
\hline & Unimproved & 0.57 & $\begin{array}{l}0.5 \\
0.6\end{array}$ & 0.000 & 0.37 & $0.3-0.4$ & 0.000 \\
\hline & $\begin{array}{l}\text { No toilet } \\
\text { facility/field/bush }\end{array}$ & & & & & & \\
\hline \multirow[t]{2}{*}{$\begin{array}{l}\text { Ever had terminated } \\
\text { pregnancy }\end{array}$} & Yes & 1.01 & $\begin{array}{l}0.8- \\
1.2\end{array}$ & 0.971 & 1.1 & $0.8-1.4$ & 0.540 \\
\hline & No & & & & & & \\
\hline Water source & Improved & 0.7 & $\begin{array}{l}0.67- \\
0.8\end{array}$ & 0.000 & 0.50 & $0.4-0.6$ & 0.000 \\
\hline
\end{tabular}

Unimproved

\section{Multivariable analysis of risk factors}

The multivariable analysis indicated that the use of biomass fuel was 1.4 times more moderate to severe anemic than clean fuel type users but the association was not statistically significant. Whereas, biomass fuel user women of reproductive age were $33 \%$ more likely to develop mild anemia than those women who use clean fuel at the household level. As indicated in (table 4), BMI, age of the women and the household head in years, the total number of household members $>3$, the total number of children born $>5$, using an unimproved water source, having no toilet, and being the poorest in wealth index matrix were factors associated with severe anemia status whereas the age of household head, BMI, education, the total residents $>3$, the total children ever born $>5$, having no toilet and being the poorest in a wealth index matrix

Table 4. Multivariable analysis of factors associated with the anemia status among women of reproductive age in Ethiopia. 
Risk factors

Fuel type

Biomass fuel

Clean fuels

\begin{tabular}{|c|c|c|c|c|c|c|c|}
\hline Age of household head & & 0.996 & $\begin{array}{l}0.99- \\
1.0\end{array}$ & 0.055 & 0.991 & $\begin{array}{l}0.985- \\
0.997\end{array}$ & 0.003 \\
\hline $\begin{array}{l}\text { Age of the women in } \\
\text { years }\end{array}$ & - & 1.0 & $\begin{array}{l}0.995- \\
1.01\end{array}$ & 0.745 & 0.987 & $\begin{array}{l}0.978- \\
0.997\end{array}$ & 0.010 \\
\hline $\mathrm{BMl}$ in $\mathrm{kg} / \mathrm{m}^{2}$ & - & 1.0 & $\begin{array}{l}1.0- \\
1.0\end{array}$ & 0.044 & 1.000 & $\begin{array}{l}0.999- \\
1.000\end{array}$ & 0.005 \\
\hline \multirow[t]{2}{*}{$\begin{array}{l}\text { Sex of head of the } \\
\text { household }\end{array}$} & Male & 0.9 & $\begin{array}{l}0.8- \\
1.01\end{array}$ & 0.069 & 0.998 & $0.8-1.2$ & 0.983 \\
\hline & Female & & & & & & \\
\hline \multirow[t]{3}{*}{ Education } & No education & 1.5 & $\begin{array}{l}1.1- \\
1.9\end{array}$ & 0.012 & 1.6 & $\begin{array}{l}0.99- \\
2.7\end{array}$ & 0.052 \\
\hline & Primary & 1.2 & $\begin{array}{l}0.9- \\
1.6\end{array}$ & 0.237 & 0.8 & $0.5-1.4$ & 0.494 \\
\hline & Secondary & 1.2 & $\begin{array}{l}0.9- \\
1.6\end{array}$ & 0.263 & 0.9 & $0.5-1.5$ & 0.647 \\
\hline
\end{tabular}

Higher

Type of place of residence

\begin{tabular}{|c|c|c|c|c|c|c|c|}
\hline & Rural & & & & & & \\
\hline \multirow[t]{5}{*}{ Wealth index } & Poorest & 1.6 & $\begin{array}{l}1.2- \\
2.0\end{array}$ & 0.000 & 3.1 & $\begin{array}{l}2.03- \\
4.7\end{array}$ & 0.000 \\
\hline & Poorer & 1.2 & $\begin{array}{l}0.9- \\
1.5\end{array}$ & 0.226 & 1.5 & $\begin{array}{l}0.95- \\
2.3\end{array}$ & 0.086 \\
\hline & Middle & 1.1 & $\begin{array}{l}0.9- \\
1.4\end{array}$ & 0.338 & 1.4 & $0.9-2.1$ & 0.135 \\
\hline & Richer & 0.9 & $\begin{array}{l}0.7- \\
1.2\end{array}$ & 0.562 & 1.2 & $0.8-1.4$ & 0.347 \\
\hline & Richest & & & & & & \\
\hline Cigarette smoking & No & 0.9 & $\begin{array}{l}0.6- \\
1.6\end{array}$ & 0.810 & 1.85 & $0.7-5.2$ & 0.239 \\
\hline
\end{tabular}




\begin{tabular}{|c|c|c|c|c|c|c|c|}
\hline & Yes & & & & & & \\
\hline \multirow[t]{2}{*}{ Chewing Khat } & No & 1.1 & $\begin{array}{l}0.9- \\
1.2\end{array}$ & 0.515 & 0.8 & $0.6-1.1$ & 0.124 \\
\hline & Yes & & & & & & \\
\hline \multirow[t]{2}{*}{$\begin{array}{l}\text { Total number of } \\
\text { household members }\end{array}$} & $\leq 3$ & 0.7 & $\begin{array}{l}0.6- \\
0.8\end{array}$ & 0.000 & 0.73 & $0.6-0.9$ & 0.005 \\
\hline & $>3$ & & & & & & \\
\hline \multirow[t]{2}{*}{$\begin{array}{l}\text { Number of under five } \\
\text { children }\end{array}$} & $\leq 5$ & 0.7 & $\begin{array}{l}0.6- \\
0.9\end{array}$ & 0.000 & 0.6 & $\begin{array}{l}0.48- \\
0.8\end{array}$ & 0.000 \\
\hline & $>5$ & & & & & & \\
\hline \multirow[t]{3}{*}{ Toilet type } & Improved & 1.2 & $\begin{array}{l}0.96- \\
1.4\end{array}$ & 0.123 & 1.625 & $1.2-2.2$ & 0.001 \\
\hline & Unimproved & 0.8 & $\begin{array}{l}0.7- \\
0.9\end{array}$ & 0.000 & 0.8 & $0.6-0.9$ & 0.008 \\
\hline & $\begin{array}{l}\text { No toilet } \\
\text { facility/field/bush }\end{array}$ & & & & & & \\
\hline \multirow[t]{2}{*}{$\begin{array}{l}\text { Ever had terminated } \\
\text { pregnancy }\end{array}$} & Yes & 1.01 & $\begin{array}{l}0.8- \\
1.2\end{array}$ & 0.926 & 1.1 & $0.8-1.4$ & 0.648 \\
\hline & No & & & & & & \\
\hline Water source & Improved & 0.99 & $\begin{array}{l}0.9- \\
1.1\end{array}$ & 0.905 & 0.8 & $\begin{array}{l}0.7- \\
0.97\end{array}$ & 0.023 \\
\hline
\end{tabular}

\section{Unimproved}

The mean difference in blood Hemoglobin level adjusted for altitude and smoking $(\mathrm{g} / \mathrm{dl})$ was assessed for biomass fuel and clean fuel users using an independent sample t-test, and the result indicated that there was a significant mean blood Hemoglobin level $(5.8 \mathrm{~g} / \mathrm{dl})$ reduction $P<0.001$ between the two groups. Non-pregnant women of reproductive age living in households that utilize biomass fuel for cooking were found to have a blood Hemoglobin level of $5.8 \mathrm{~g} / \mathrm{dl}$ lower than those women who reside in households with clean fuels such as electricity.

\section{Discussion}

To the researchers' knowledge, this research is the first to assess the link between indoor air pollution arising from cooking fuels and the anemia status among non-pregnant women in Ethiopia using nationwide data. In this finding, the proportion of anemia was found to be higher among biomass fuel users than the clean fuel users where anemia status was observed in $29.4 \%$ of the biomass fuel users and only in $16.2 \%$ of lean fuel users. This finding was similar to a finding done in Ghana where women who were using biomass fuels were $36.4 \%$ more anemic than women who were using cleaner fuels $20.5 \%$ 
[23]. The result also showed a $5.8 \mathrm{~g} / \mathrm{dl}$ lower blood hemoglobin of level in the biomass fuel users when compared with the clean fuel users. This finding was in line with the finding reported by [24], where participants who live in households that cook with traditional biomass fuels had low hemoglobin values.

The finding indicated that high polluting fuel use was not associated with moderate to severe anemia in logistic regression, whereas the use of biomass fuel was linked with reduced blood hemoglobin level in non-pregnant women in Ethiopia and also linked with an increased odds of mild anemia. This was in agreement with a finding done in Ghana where women who smoke fish as their primary livelihood using biomass fuel were at an increased risk of being anemic considering other dietary factors into consideration [23].

The link between the cooking fuel use and the anemia status can be explained by the role of the indoor air pollutants arising from biomass fuel in triggering systemic inflammation, caused by which could finally lead to iron homeostasis, impaired erythropoietin response to reduced hemoglobin levels, and impaired marrow response to erythropoietin [25].

Our finding also indicated that lower body mass index was associated with both moderate to severe and mild anemia in non-pregnant women in Ethiopia. This is consistent with a recent study finding among younger adults in Ethiopia [26], where a higher body mass index was associated with lower anemic status. A higher body mass index may not necessarily mean that all the necessary micro-nutrient demands are met, but the lower body mass index is the main risk factor for many adverse health outcomes among non-pregnant women of reproductive age including anemia [27].

Indoor air pollution from biomass fuel is associated with many adverse health outcomes in developing countries. To tackle these adverse health outcomes such as anemia, arising from the use of biomass fuels for cooking, could be reduced through different interventions such as the provision of improved cookstove at the household level [28].

\section{Strength and limitation of this study}

The main strength of this finding is the use of a large representative sample size which can be generalized at the national level. But the variation in the type of fuel types used, the duration of exposure to indoor air pollution, and feeding habits were not taken into consideration during this analysis. Therefore, care should be taken for the interpretation of the result.

\section{Conclusion}

The finding indicated that the use of biomass fuel was associated with reduced blood Hemoglobin levels and significantly associated with mild anemia levels in women of reproductive age in Ethiopia. Interventions that reduce or prevent indoor air pollution from biomass fuels must be implemented in Ethiopia. 


\section{Declarations}

Acknowledgment

\section{We are very much thankful to DHS ICF, USA for providing us the permission as well as the national data set. Our special thanks go to Wellington Bridgette, for her unreserved support in the entire process.}

\section{Data availability statement}

The survey data we used for this research can be accessed online from the Demographic and Health Survey program website through the following link:

http:// dhsprogram.com/data/available-datasets.cfm

Author's contribution

Girum Geberemeskel Kanno and Robel Hussen: conceptualization, investigation, project administration, methodology, Formal analysis, writing the original draft.

Temesgen Geremew and Tesfaye Diro: methodology, data curation, analysis, editing, and writing

Biniam Tariku and Awash Alembo: methodology, data curation, analysis, editing, writing and manuscript preparation.

Renay Van Wyk and Stephen Vincent Musarapi: methodology, data curation, analysis, editing, writing, and manuscript preparation.

Mekonnen Birhanie Aregu Negassa Eshete Saboksa: methodology, data curation, analysis, editing, supervision, writing, and manuscript preparation.

Competing interests

The authors have no conflict of interest to declare, financial or otherwise.

Funding

The authors did not receive any financial support or funding for this research.

Ethical considerations

This study is excepted from Ethical considerations because we have used secondary data for the analysis. However, a request was made to DHS and a permission letter was granted to utilize the data set. 


\section{References}

1. Young $M F<\mathrm{bi}>.</ \mathrm{bi}>$ Maternal anaemia and risk of mortality. a call for action $<\mathrm{bi}>.</ \mathrm{bi}>$ Lancet Glob Health. 2018<bi $></$ bi $>6<\mathrm{bi}>(</ \mathrm{bi}>5<\mathrm{bi}>):</ \mathrm{bi}>e 479-e 80<\mathrm{bi}>.</ \mathrm{bi}>$

2. Organization WH. Global technical strategy for malaria 2016-2030: World Health Organization; 2015.

3. Geneva S, Organization WH. Haemoglobin Concentrations for the Diagnosis of Anemia and Assessment of Severity. Vitamin and Mineral Nutrition Information System. Document Reference WHO. NMH/NHD/MNM/11.1. 2011 http://www.who.int/entity/vmnis/indicators/haemoglobin.

4. Daru $J<\mathrm{bi}>,</ \mathrm{bi}>$ Zamora $J<\mathrm{bi}>,</ \mathrm{bi}>$ Fernández-Félix $B M<\mathrm{bi}>,</ \mathrm{bi}>$ Vogel $J<\mathrm{bi}>,</ \mathrm{bi}>$ Oladapo $O T<\mathrm{bi}></ \mathrm{bi}>$ Morisaki $\mathrm{N}<\mathrm{bi}>$, et al.</bi $>$ Risk of maternal mortality in women with severe anaemia during pregnancy and post partum: a multilevel analysis<bi $></$ bi $>$ Lancet Glob Health<bi $>$. $</ \mathrm{bi}>$ $2018<\mathrm{bi}>;</ \mathrm{bi}>6<\mathrm{bi}>(</ \mathrm{bi}>5<\mathrm{bi}>):</ \mathrm{bi}>e 548-e 54$

5. WHO. Hemoglobin concentrations for the diagnosis of anemia and assessment of severity. Vitamin and Mineral Nutrition Information System. Geneva: WHO;2011: Available from: http://www.who.int/vmnis/indicators/ haemoglobin.pdf

6. Benoist $B D<\mathrm{bi}>,</ \mathrm{bi}>M C L$ ean $E<\mathrm{bi}>,</ \mathrm{bi}>$ Egli $k \mathrm{bi}>,</ \mathrm{bi}>$ Cogswell $M<\mathrm{bi}>.</ \mathrm{bi}>$ Worldwide prevalence of anaemia 1993-2005<bi>. In:</bi> WHO Global Database on Anemia<bi>,</bi $2008<\mathrm{bi}>.</$ bi $>$

7. Guidotti $R J<\mathrm{bi}>.</ \mathrm{bi}>$ Anemia in pregnancy in developing countries<bi $>.</ \mathrm{bi}>B J O G<b \mathrm{bi}>.</ \mathrm{bi}>$ $2000<\mathrm{bi}>;</ \mathrm{bi}>107<\mathrm{bi}>(</ \mathrm{bi}>4<\mathrm{bi}>):</ \mathrm{bi}>437-8<\mathrm{bi}>$. doi $<</ \mathrm{bi}>$ 10

$.1111 /$ j.1471-0528.2000.tb13258.x<bi>.</bi>

8. Ethiopian Central Statistical Agency: Ethiopian Demographic and Health Survey report: Key Indicators Report. The DHS Program ICF. 2016.

9. Haidar J. Prevalence of anemia, deficiencies of iron and folic acid and their determinants in Ethiopian women. J Health Popul Nutr. 2010;28(4):359.

10. Yip R, Ramakrishnan U. Experiences and challenges in developing countries. J Nutr. 2002;132(4 Suppl):827S-30S. https://doi.org/10.1093/jn/132.4.827S. PMID: 11925490.

11. Petry N, Olofin I, Hurrell RF, Boy E, Wirth JP, Moursi M, Donahue Angel M, Rohner F. The Proportion of Anemia Associated with Iron Deficiency in Low, Medium, and High Human Development Index Countries: A Systematic Analysis of National Surveys. Nutrients. 2016;8(11):693. https://doi.org/10.33 90/nu8110693. PMID: 27827838; PMCID: PMC5133080.

12. Balarajan Y, Ramakrishnan U, Özaltin E, Shankar AH, Subramanian SJT. Anemia in low-income and middle-income countries. 2011;378(9809):2123 - 35

13. Ramakrishnan U, Grant F, Goldenberg T, Zongrone A, Martorell R. Effect of women's nutrition before and during early pregnancy on maternal and infant outcomes: a systematic review. Paediatr Perinat Epidemiol 2012; 26: 285-301. 
14. Mishra V., and Retherford R.D., 2007. "Does biofuel smoke contribute to anemia and stunting in early childhood?", International Journal of Epidemiology, vol. 36, no. 1, pp. 117-129, doi:10.1093/ije/dyl234

15. Page CM, Patel A, Hibberd PL (2015) Does Smoke from Biomass Fuel Contribute to Anemia in Pregnant Women in Nagpur, India? A CrossSectional Study. PLoS ONE 10(5): e0127890. doi:10.1371/journal.pone.0127890

16. Andarge S. D., Areba A. S., Kabthymer R.H., Legesse M. T, and Kanno G.G., 2021. Is Indoor Air Pollution From Different Fuel Types Associated With the Anemia Status of Pregnant Women in Ethiopia? Journal of Primary Care \& Community Health Volume 12: 1-8. DOl: $10.1177 / 21501327211034374$

17. World Health Organization<bi>,</bi> 2014<bi>. Fact Sheet No 292: Household Air Pollution and Health.</bi>

18. $L a m<\mathrm{bi}>,</ \mathrm{bi}>N . L .<\mathrm{bi}>,</ \mathrm{bi}>$ Smith $<\mathrm{bi}>,</ \mathrm{bi}>K . R .<\mathrm{bi}>,</ \mathrm{bi}>$ Gauthier $<\mathrm{bi}>,</ \mathrm{bi}>A .<\mathrm{bi}>$, and $</ \mathrm{bi}>$ Bates $<\mathrm{bi}>,</ \mathrm{bi}>$ M.N.<bi $></ \mathrm{bi}>2012<\mathrm{bi}>,</ \mathrm{bi}>$ Kerosene: a review of household uses and their hazards in low- and middle-income countries $<\mathrm{bi}>.</ \mathrm{bi}>$ Journal of toxicology and environmental health Part $B$, Critical reviews $15<\mathrm{bi}>(</ \mathrm{bi}>6<\mathrm{bi}>),</ \mathrm{bi}>396-432$ ://doi.org/10.1080/10937404.2012.710134

19. World Population Review 2021. Accessed from (Ethiopia Population 2021 (Demographics, Maps, Graphs) (worldpopulationreview.com)

20. Ethiopian Central Statistical Agency: Ethiopian Demographic and Health Survey report: Key Indicators Report. The DHS Program ICF. 2016.

21. N. J. Kassebaum, "The global burden of anemia," Hematology/ Oncology Clinics of North America, vol. 30, no. 2, pp. 247-308, 2016. https://doi.org/10.1016/j.hoc.2015.11.002

22. Mishra, V., Dai, X., Smith, K. R., \& Mika, L. (2004). Maternal exposure to biomass smoke and reduced birth weight in Zimbabwe. Annals of Epidemiology, 14(10), 740-747.

https://doi.org/10.1016/j.annepidem.2004.01.009

23. Armo-Annor D., Esi K. C., Adu-Afarwuah S., Christian A. K., and Jones A. D., 2021.Risk of anemia among women engaged in biomass-based fish smoking as their primary livelihood in the central region of Ghana: a comparative cross-sectional study. BMC Nutrition. 7:50 https://doi.org/10.1186/s40795-021-00456-w

24. Padhy P, Padhi B. Effects of biomass combustion smoke on hemotological and antioxidant profile among children (8-13 years) in India. Inhal Toxicol. 2009;21(8):705-11. https://doi.org/10.1080/08958370802448961.

25. WHO. Air Quality Guidelines. 1999.

26. Tusa1 B.S.,Kebede S. A., and Weldesenbet A. B., 2021. Spatial distribution and determinant factors of anemia among adults aged 15-59 in Ethiopia; using mixed-effects ordinal logistic regression model. BMC Nutrition. 7:18 https://doi.org/10.1186/s40795-021-00424-4 
27. Adamu AL, Crampin A, Kayuni N, Amberbir A, Koole O, Phiri A, et al. Prevalence and risk factors for anemia severity and type in Malawian men and women: urban and rural differences. Popul Health Metrics. 2017;15(1):12.

28. Adane M.M., Alene G. D., and Mereta S. T., 2021. Biomass-fuelled improved cookstove intervention to prevent household air pollution in Northwest Ethiopia: a cluster randomized controlled trial.

Environmental Health and Preventive Medicine 26:1 https://doi.org/10.1186/s12199-020-00923-z

\section{Figures}

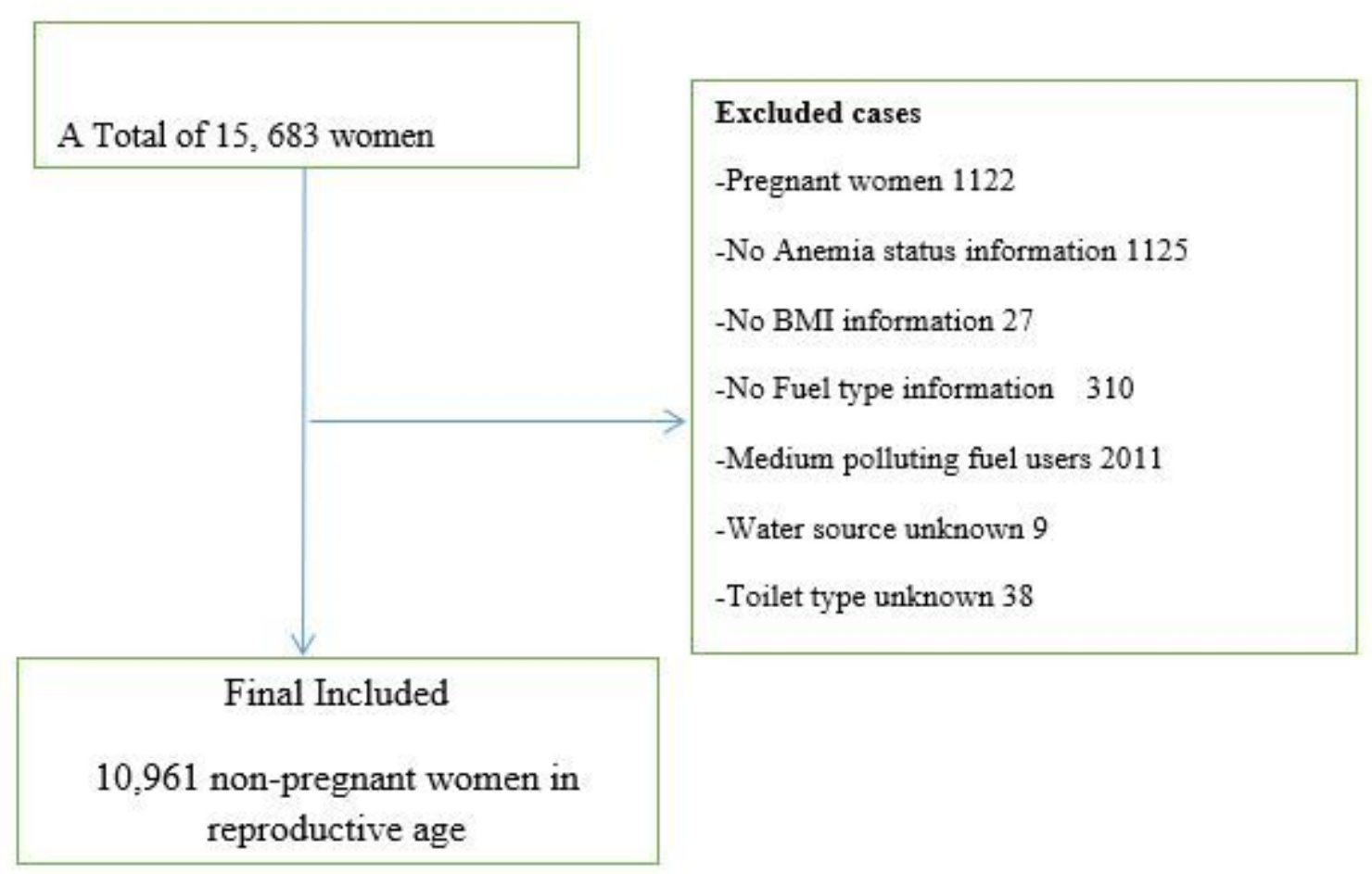

\section{Figure 1}

Included and excluded cases for the study. 


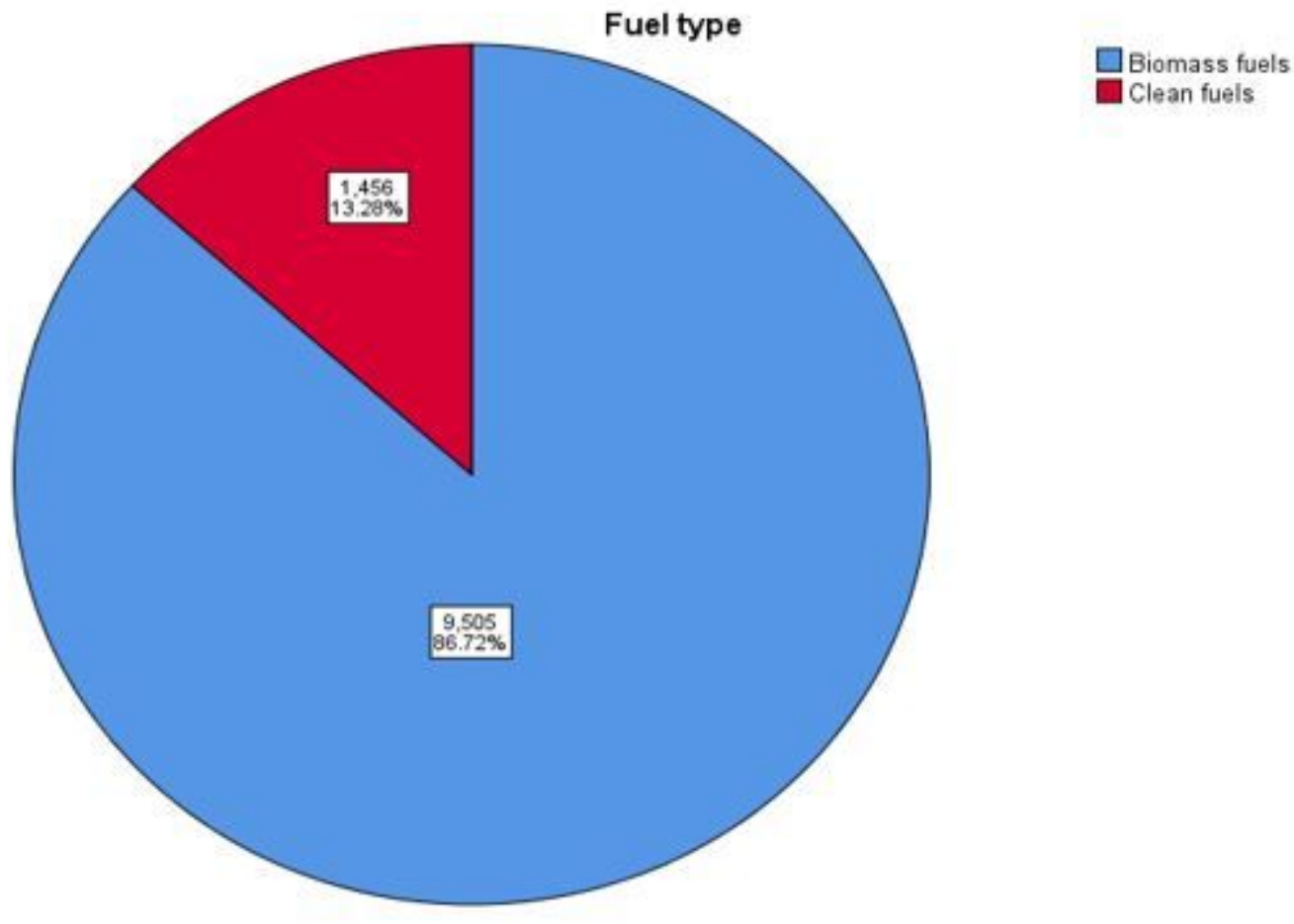

Figure 2

Fuel type categories utilized by the non-pregnant women in Ethiopia 